\title{
The Flow of Antarctic Bottom Water into the Brazil Basin
}

\author{
KEVIN G. SPEER \\ Laboratoire de Physique des Océans, IFREMER, Plouzané, France \\ WALTER ZENK \\ Institut für Meereskunde, Kiel, Germany \\ (Manuscript received 18 February 1993, in final form 5 April 1993)
}

\begin{abstract}
The total transport of Antarctic Bottom Water across the Rio Grande Rise, including the western boundary, the Vema Channel, and the Hunter Channel is estimated from hydrographic measurements across these pathways. The contribution of the Vema Channel is greatest at $3.9 \times 10^{6} \mathrm{~m}^{3} \mathrm{~s}^{-1}$, which is very close to earlier estimates. The western boundary current contribution is $2.0 \times 10^{6} \mathrm{~m}^{3} \mathrm{~s}^{-1}$ and that of the Hunter Channel $0.7 \times 10^{6}$ $\mathrm{m}^{3} \mathrm{~s}^{-1}$. The lower values outside the Vema Channel are offset by the important source of mass they form to the lower density classes of bottom water. About $40 \%$ of the flow is concentrated in the highest density class representing the source of Weddell Sea Deep Water to the Brazil Basin. The flow structure is characterized by horizontal and vertical recirculation.
\end{abstract}

\section{Introduction}

Dense Antarctic Bottom Water formed around the Antarctic continent spreads northward from basin to basin to cover much of the world's seafloor. In the South Atlantic the densest water comes from the Weddell Sea and is guided into the Argentine Basin by ridges, troughs, and passages and by the earth's rotation (Fig. la). There the bottom water is confined by the Mid-Atlantic Ridge to the east and the Rio Grande Rise to the north. The primary pathway through which bottom water continues north is the Vema Channel, which cuts across the Rio Grande Rise separating the Argentine Basin from the Brazil Basin (Fig. 1b). A central elevation forms two gaps in the rise, with the Vema Channel to the west and the Hunter Channel to the east. Although Wüst (1933) established the importance of the western gap, he thought the eastern passage sufficiently shallow to inhibit the flow of Antarctic Bottom Water. Later measurements (Fuglister 1960) appeared to confirm Wüst's (1933) suspicion that the flow was limited to the western passage (Reid et al. 1977). The role of the Vema Channel as a pathway for bottom water has been investigated with dedicated expeditions by Johnson et al. (1976) and Hogg et al. (1982). In the latter, a combination of long current meter measurements and hydrography indicated a transport of $4 \times 10^{6} \mathrm{~m}^{3} \mathrm{~s}^{-1}$ of Antarctic Bottom Wa-

Corresponding author address: Dr. Kevin G. Speer, Laboratoire de Physique des Océans, IFREMER, B.P. 70, 29280 Plouzane, France. ter through the channel. The contribution of the Hunter Channel, on the other hand, had never been adequately resolved in earlier studies; Speer et al. (1992) report a bottom water transport of $0.7 \times 10^{6}$ $\mathrm{m}^{3} \mathrm{~s}^{-1}$ through the Hunter Channel using a subset of the measurements described here. The importance of determining the total flow of bottom water across the rise is emphasized by the absence of any significant transport across the Walvis Ridge on the eastern side of the Mid-Atlantic Ridge (Warren and Speer 1991). Thus, the flow across the Rio Grande Rise supplies essentially the entire Atlantic Ocean north of about $30^{\circ} \mathrm{S}$ with Antarctic Bottom Water.

A number of dynamical ideas related to the confinement and concentration of flow by topography have been brought up in past studies. These include the steering of the northward flowing deep western boundary current, hydraulic and frictional effects, and the vertical influence of flow through a channel on horizontal flow in overlying water mass layers. These ideas are important to reconsider in a description of the hydrography because they form the basis for understanding the nature of mixing, which controls water mass modification. Observations discussed here of flow in and outside the Vema Channel show some of the features that originally motivated the new dynamical explanations in a different setting. For instance, the shear reversal and peculiar density structure attributed to friction and mixing by Johnson et al. (1976) and to hydraulic effects by Hogg (1983) also occurs in the Hunter Channel, a much weaker flow regime.

In addition to the Vema Channel and the Hunter 

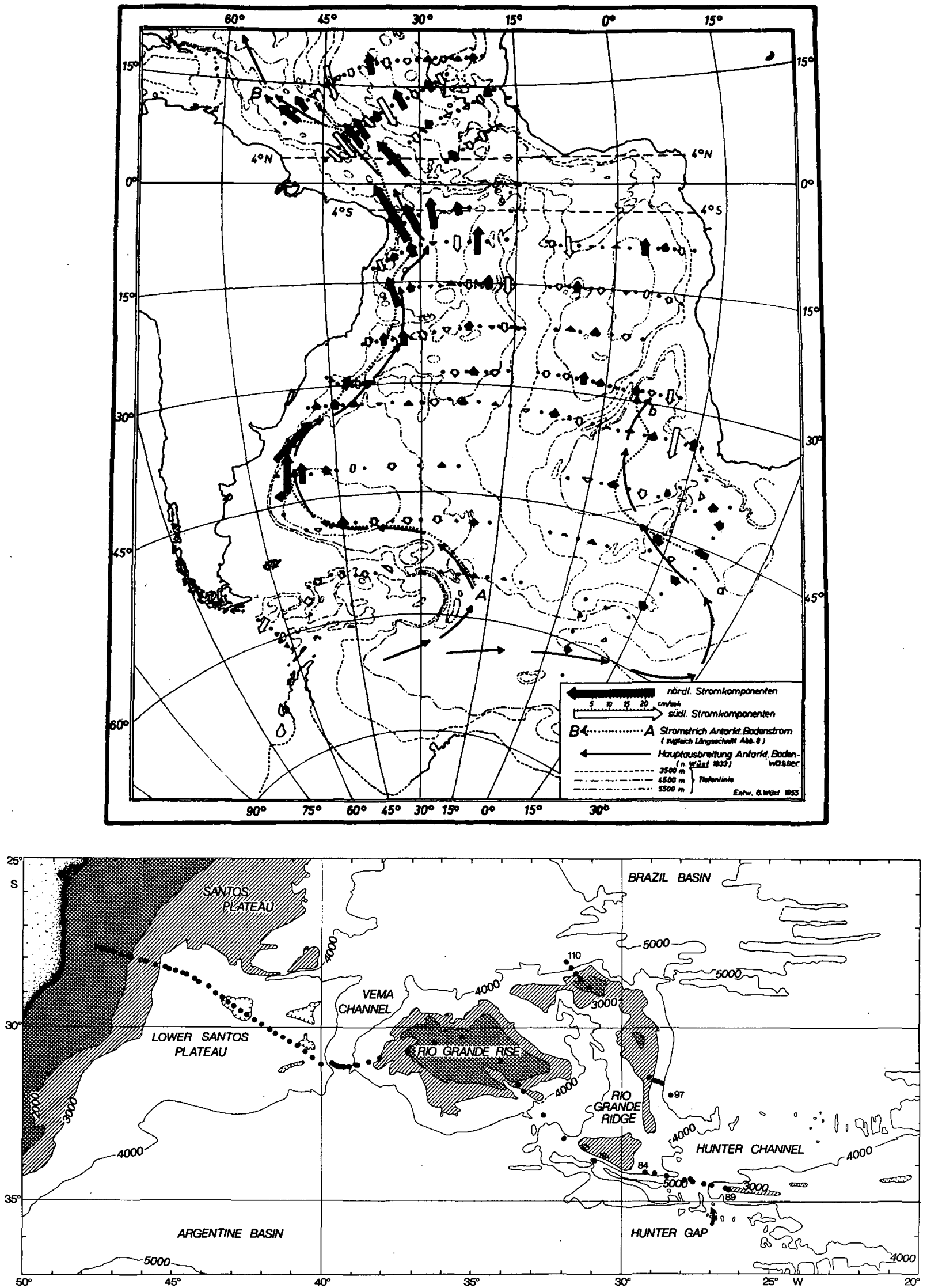
Channel, a third zone of particular importance to bottom water flow across the rise is the Lower Santos Plateau to the west of the Vema Channel. At a depth of roughly $4000 \mathrm{~m}$, it lies well below the depth of the $2^{\circ} \mathrm{C}$ isotherm on the eastern boundary in the Argentine Basin (usually thought of as the upper boundary of bottom water), and therefore might seem likely to allow the passage of at least the upper portion of this water mass. This zone will be seen to contribute a transport intermediate between those of the Vema and Hunter.

The main objective of this paper is to present the total transport of Antarctic Bottom Water across the Rio Grande Rise, including the western boundary, Vema Channel, and Hunter Channel. Sometimes this water mass is split into several layers reflecting circumpolar or distinct Weddell Sea origins (Reid et al. 1977). To determine the role of each sublayer and yet avoid ambiguities about water mass definition, the transport can be divided into density classes. The measurements used to make this calculation were obtained by the F.S. Meteor (Cruise 15) during January-February 1991, nominally at $30^{\circ} \mathrm{S}$. The hydrographic section so obtained extends from the (wide) shelf off South America to the flank of the Mid-Atlantic Ridge. The easternmost station on the flank was placed on a zonal extension of a ridge to reduce the chance that any flow farther to the east was missed. For comparison, similar transport calculations were made using data from leg 3 of Meteor 15 at $19^{\circ} \mathrm{S}$ and also R.V. Oceanus (Cruise 133) stations at $11^{\circ} \mathrm{S}$ and $24^{\circ} \mathrm{S}$, occupied in 1983 .

\section{Meteor 15 hydrographic data}

Due to mooring activity for the first, western leg of the cruise up to the Vema Channel, the pace was slow and it was possible to occupy stations every $20 \mathrm{~km}$ on average outside the Vema Channel, producing a very high-resolution section. Within the channel, the station spacing was about $4 \mathrm{~km}$, that is, approximately the water depth. The eastern leg was occupied a few weeks later with stations concentrated in the Hunter Channel. Complete logistical and operational details for all legs can be found in Siedler and Zenk (1992).

All stations during legs 1 and 2 were made with a Niel Brown Mark III CTD, with an oxygen sensor and bottom alarm, to within $15 \mathrm{~m}$ of the bottom. Water samples were collected with a General Oceanics 101 rosette. Usually 12 levels were sampled for salinity and oxygen calibration purposes only; on the second leg a number of 24-bottle tracer stations were occupied as well (Siedler and Zenk 1992). Salinity samples were analyzed on a Guildline Autosal 8400A using standardizations with IAPSO water batch P112. Salinometer problems on leg 2 necessitated carrying over corrections calculated for leg 1 onto leg 2 stations.

Temperature was calibrated consistent with routine laboratory calibrations before and after the cruise. The final values are considered to be accurate to $0.002^{\circ} \mathrm{C}$. Calibrated pressure measurements (nondynamic corrections) are thought accurate to $3 \mathrm{db}$, except on a few stations with unexplained gradual increases of about $10 \mathrm{db}$ toward the bottom. Salinity calibration resulted in a final accuracy of 0.005 psu.

Oxygen samples were analyzed according to the Winkler-Grasshoff method. A consistent oxygen calibration for the entire section was possible (and necessary, given the relatively small number of samples), producing a final accuracy of $0.1 \mathrm{ml} \mathrm{l}^{-1}$ for the CTD oxygen measurements. The overall accuracy of the titration values is more nearly $0.02 \mathrm{ml} \mathrm{l}^{-1}$.

\section{Deep property distributions}

Distributions of potential temperature, salinity, potential density, and dissolved oxygen concentration for the full Rio Grande Rise section from the Brazilian shelf to $26^{\circ} \mathrm{W}$ are displayed in Figs. 2a-d. First, the property distributions in the three principal deep layers (Antarctic Intermediate Water, North Atlantic Deep Water, and Antarctic Bottom Water) will be discussed briefly in the context of the full section. This provides a background to the subsequent focus on the distinct zones of bottom water flow: the Santos Plateau, the Vema Channel, and the Hunter Channel.

\section{a. The full Rio Grande Rise section}

The bathymetry along the section is dominated by the central high or plateau rising to depths less than $1000 \mathrm{~m}$. The deepest point to the west of the central high is the Vema Channel near $39^{\circ} \mathrm{W}$. Just east of the central high is a deep fracture zone of over $5000-\mathrm{m}$ depth, evidently isolated from its surroundings below a depth of about $4100-4200 \mathrm{~m}$. To the east of this is the wider Hunter Channel $\left(26^{\circ}-30^{\circ} \mathrm{W}\right)$ between the Rio Grande Ridge and a smaller elevation adjoining the Mid-Atlantic Ridge. Farther east, beyond the section, depth increases to $3800-4000 \mathrm{~m}$ and then the seafloor rises toward the crest of the Mid-Atlantic Ridge near $15^{\circ} \mathrm{W}$.

Beneath the main thermocline, at temperatures of around $4^{\circ} \mathrm{C}$ and depths of about $800 \mathrm{~m}$, salinity de-

FIG. 1. (a) Reproduction of Wüst's (1955) regional distribution of near-bottom current $(>3500 \mathrm{~m}$ ) components normal to the $M$ Meteor sections of the Deutsche Atlantische Expedition. Note the continuous band of strong currents at the western side of the South Atlantic basins. (b) Bottom topography of the Rio Grande Rise according to Cherkis et al. (1989). The Rio Grande Rise separates the Argentine Basin to the south from the Brazil Basin. Meteor Cruise 15 included a CTD section (stations 1-89) between the shelf off Brazil and the Hunter Channel. Additional short sections were taken from the eastern (stations 97-101) and northern (stations 107-110) sides of the Rio Grande Ridge. 

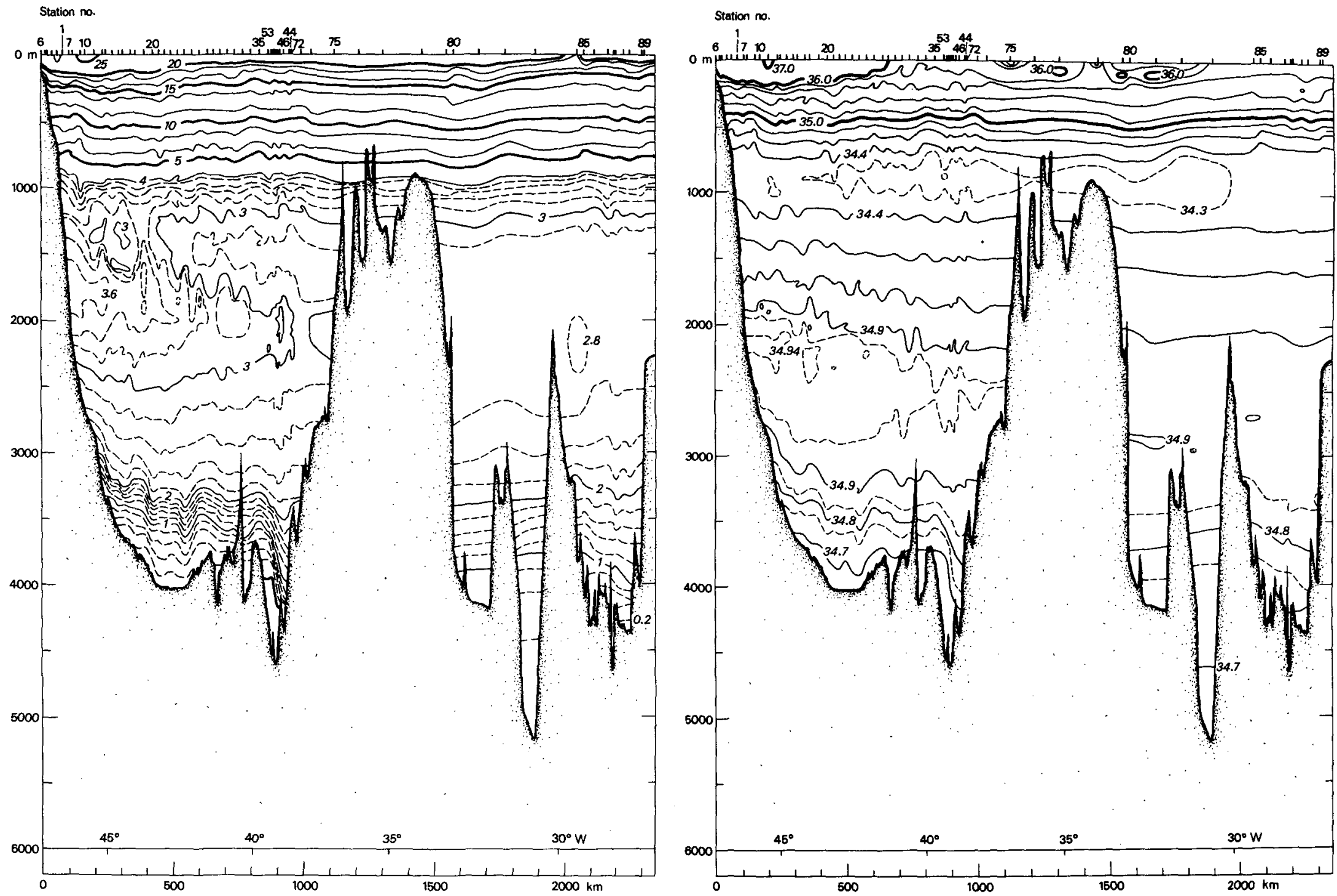

FIG 2. (a) Profile of potential temperature $\left({ }^{\circ} \mathrm{C}\right.$ ) along the Rio Grande Rise as indicated by Meteor Cruise 15 stations 1-89, January-February 1991. Station number along top, depth scale $(\mathrm{m})$ along sides, and distance $(\mathrm{km}$ ) along bottom axis. Nominal longitude (not a uniform scale) is shown at bottom, vertical distortion is 500:1. South America at left edge, Vema Channel at $900 \mathrm{~km}$, central plateau in middle, and Hunter Channel near $2200 \mathrm{~km}$ (see Fig. 1). (b) Profile of salinity (psu) along Rio Grande Rise. (c) Profile of potential density anomaly referenced to 4000 dbar (lower), $2000 \mathrm{dbar}$ (middle), and 0 dbar (upper water column, $\mathrm{kg} \mathrm{m}^{-3}$, EOS 80 ) along the Rio Grande Rise. (d) Profile of dissolved-oxygen concentration ( $\mathrm{ml} 1^{-1}$ ) along Rio Grande Rise. (e) Temperature-salinity diagram representative of three regions on the Rio Grande Rise. Each group was shifted by $1.5^{\circ} \mathrm{C}$ and $0.5 \mathrm{psu}$ 

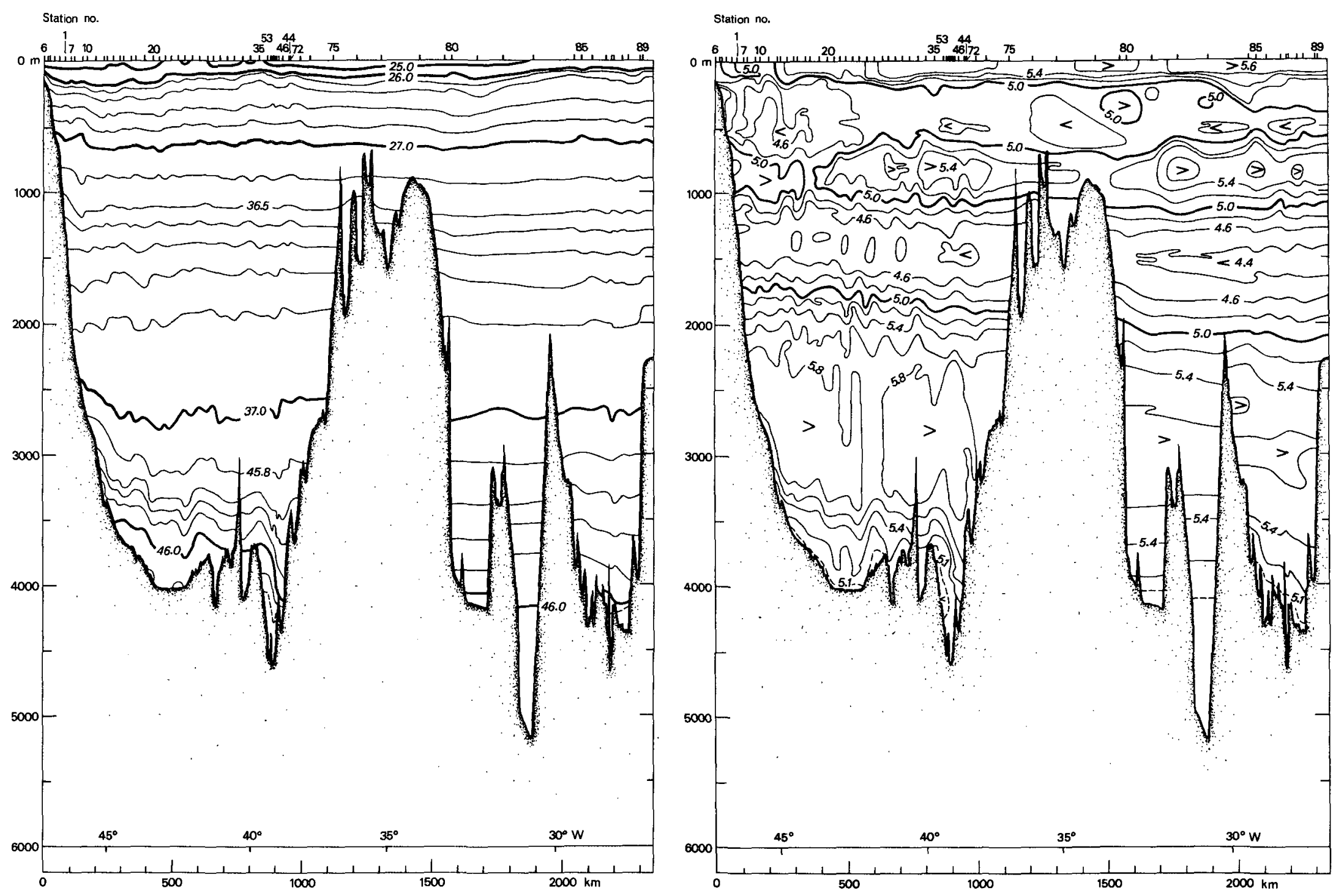

FIG. 2 (Continued) referenced to $4000 \mathrm{dbar}$ (lower), $2000 \mathrm{dbar}$ (middle), and $0 \mathrm{dbar}$ (upper water column, $\mathrm{kg} \mathrm{m}^{-3}$, EOS 80 ) along the Rio Grande Rise. (d) Profile of dissolved-oxygen along Rio Grande Rise. (e) Temperature-salinity diagram representative of three regions on the Rio Grande Rise. Each group was shifted by $1.5^{\circ} \mathrm{C}$ and $0.5 \mathrm{psu}$. 


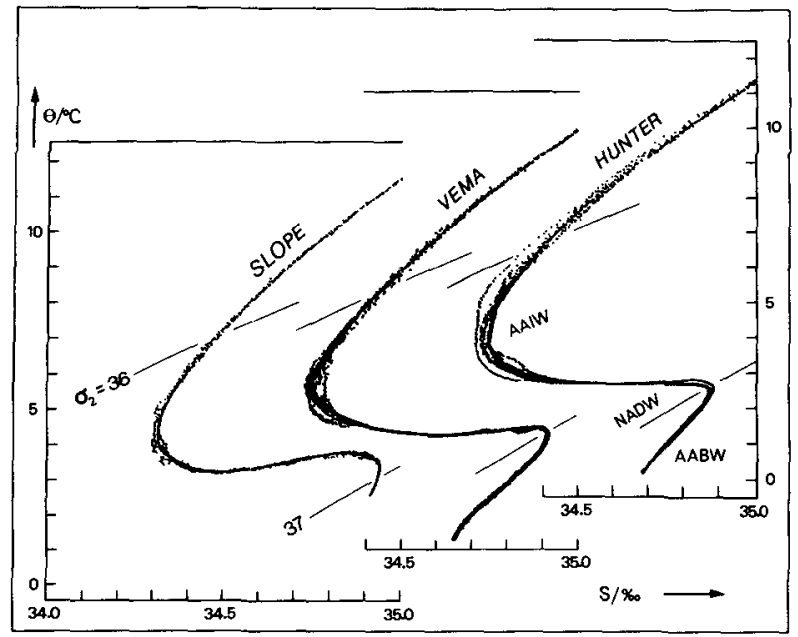

Fig. 2. (Continued)

creases to a minimum with values below 34.4 psu (Fig. $2 \mathrm{~b})$. Rather than being concentrated next to the western boundary, as is the case at latitudes to the north or to the south (Reid 1989), the salinity minimum of Antarctic Intermediate Water is strongest offshore. The minimum weakens above the central plateau, and then strengthens again on the eastern side. These horizontal salinity variations are correlated with oxygen variations corresponding to stronger or weaker intermediate water characteristics (Fig. 2d). As the motion in this layer is thought to be closely tied to that in the thermocline (Reid 1989), some intermediate water is evidently brought to the Rio Grande Rise in the northward recirculation of the Brazil Current.

At deeper levels oxygen concentrations decrease to less than $4.6 \mathrm{ml} \mathrm{l}^{-1}$ in the west, and further, to less than $4.4 \mathrm{ml}^{-1}$ in the east (Fig. 2d). Then both oxygen concentration and salinity increase to a maximum in North Atlantic Deep Water at depths roughly between 2000-3000 m. These characteristics are strongest at the western boundary near a depth of $2200 \mathrm{~m}$. Lateral mixing with the lower oxygen values and salinities in the circumpolar deep water in the Argentine Basin generates small-scale structure in the property distributions, better resolved in the western half of the section with more closely spaced stations, and degrades the North Atlantic Deep Water characteristics (e.g., along the isopycnal $36.9 \mathrm{~kg} \mathrm{~m}^{-3}$ ). Indeed, deep water suffers a greater salinity change crossing the Rio Grande Rise than during the entire path along the western boundary from $60^{\circ} \mathrm{N}$ to $30^{\circ} \mathrm{S}$.

Antarctic Bottom Water here is everything below roughly $2^{\circ} \mathrm{C}$ or $45.85 \mathrm{~kg} \mathrm{~m}^{-3}$. It is colder, fresher, and less oxygenated than the water above it. The general decrease in oxygen concentration toward the bottom is, however, reversed in the Vema Channel where an oxygen minimum is barely visible close to $4000-\mathrm{m}$ depth and $0^{\circ} \mathrm{C}$. This marks the transition to Weddell
Sea deep water, whose oxygen concentrations have been raised by contact with newly formed bottom water in the Weddell Sea (Reid et al. 1977).

A $\theta-S$ diagram was compiled from groups of individual CTD stations to show water mass characteristics in three locations (Fig. 2e). Data are equally spaced in the vertical ( $5 \mathrm{dbar}$ ). These groups make up ensembles of neighboring observations representative of several regions: the slope west of the Lower Santos Plateau, the Vema Channel, and the Hunter Channel. They cover a quasi-zonal section of over $2300 \mathrm{~km}$. For better discrimination the three curves have been shifted by multiples of $1.5^{\circ} \mathrm{C}$ and 0.5 psu.

Temperature and salinity both decrease through the thermocline waters between $12^{\circ}$ and $8^{\circ} \mathrm{C}$. The level below the main thermocline is occupied by the Antarctic Intermediate Water, which shows a well-pronounced average horizontal salinity gradient of order $0.1 \mathrm{psu} / 1000 \mathrm{~km}$. A similar trend exists in the North Atlantic Deep Water (Figs. 2b, 2e). Both vertical and lateral mixing can produce such trends, but a signifcative role for vertical mixing may be indicated by the virtual elimination of curvature on the curve connecting the two water masses in the east.

Isopycnals slope steeply next to the western boundary reflecting vertical shear between the deep and bottom water masses. Above the Lower Santos Plateau the isopycnals have a bowl-like form similar to the topography as far as $1000 \mathrm{~m}$ off the bottom, indicating a partial recirculation there. The horizontal density gradient sharpens considerably at the Vema Channel as isopycnals deepen by several hundred meters over a distance of about $50 \mathrm{~km}$. To the east, single stations to the deepest points of the central valley and within the fracture zone provide the stratification but do not resolve the horizontal density gradient below $3500 \mathrm{~m}$ at these locations. A group of closely spaced stations placed across the Hunter Channel resolve a northward (geostrophic) flow, concentrated near the bottom (Speer et al. 1992). The western boundary for this flow is the Rio Grande Ridge (Fig. 1), and so it is topographically separated from the flow through the Vema Channel.

\section{b. The Lower Santos Plateau}

The Lower Santos Plateau (Fig. 1) between the Vema Channel and the continental slope is rarely deeper than $4000 \mathrm{~m}$, but is nevertheless deep enough to permit the passage of bottom water warmer than about $0.2^{\circ} \mathrm{C}$ (Fig. 2a). Geostrophic transport calculations (see below) using a zero velocity reference surface of $2^{\circ} \mathrm{C}$ give a total northward transport below $2^{\circ} \mathrm{C}$ of roughly $3 \times 10^{6} \mathrm{~m}^{3} \mathrm{~s}^{-1}$ and a total southward transport of $1 \times 10^{6} \mathrm{~m}^{3} \mathrm{~s}^{-1}$ for a net transport northward of $2 \times 10^{6} \mathrm{~m}^{3} \mathrm{~s}^{-1}$ (stations $6-35$ ). This flow is presumably forced to follow the $3000-\mathrm{m}$ isobath around to the east somewhat north of the section, and enter 
the Brazil Basin west of the Vema Channel outflow. Thereafter the flow is free to merge with the upper part of the Vema Channel outflow and continue north.

\section{c. The Vema Channel}

The coldest water on the section, $-0.175^{\circ} \mathrm{C}$, was found at station 49 on the bottom of the Vema Channel (Fig. 3). This station was on the eastern side of the channel, where the coldest water occurs (Fig. 4). The curious fact that the coldest water is on the right looking downstream, despite the Coriolis force to the left, was explained by Johnson et al. (1976) as the result of secondary circulation in the bottom Ekman layer, and by Hogg et al. (1982) as an inviscid response of the lowest layers to accelerating flow in the layers above them. The isotherm or isopycnal slope reversal would then be an attempt by the flow to conserve the mass flux (Hogg 1983). Also evident on the section is a weak doming over a ridge located at $20 \mathrm{~km}$ distance. This ridge ends a few kilometers to the north, and some of the flow returns south in a side valley before being guided back to the main channel not far downstream (Zenk et al. 1993).

Directly above the eastern wall of the channel near $2000 \mathrm{~m}$ depth an anomalous filament of cool water appears (Fig. 4). This anomaly occurs over several stations and contains water relatively fresh and low in oxygen (Fig. 5). This is circumpolar water from the south, or deep water with stronger circumpolar characteristics acquired in the Argentine Basin. In support of this interpretation, the Vema Channel section net transport between $1500 \mathrm{~m}$ and $2500 \mathrm{~m}$ depth is zero (using a $2^{\circ} \mathrm{C}$ reference surface, see below), with southward transport over the western half compensating a northward transport east of station 43 to station 46 . Hogg et al. (1982) described a filament of North Atlantic Deep Water above the Vema Channel $(2500 \mathrm{~m})$

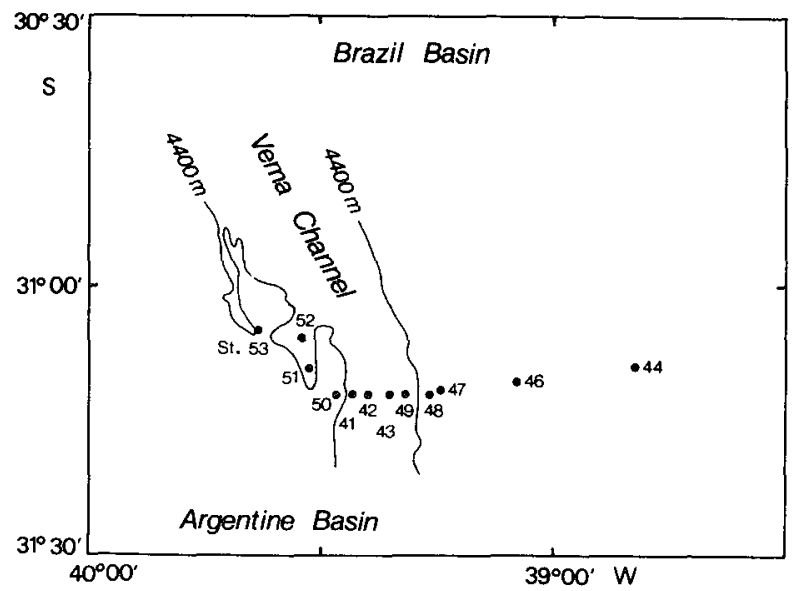

FlG. 3. Positions of $\mathrm{CTD} / \mathrm{O}_{2}$ stations in the Vema Channel. For a detailed topographic map of this sill region see Zenk et al. (1993). as evidence for the vertical dynamical influence of the channel; apparently this influence extends to slightly shallower depths, and gives rise to filaments of water both from the north and from the south. At deeper levels in the range 3500-4000 m Hogg et al. (1982) also noted the presence of temperature-salinity anomalies of 0.02 psu in the northward flowing bottom water. These variations were again observed (Fig. 6), emphasizing the probable importance of lateral mixing over a broad range of levels in deep water above the channel.

Figure 6 also illustrates the oxygen minimum within the Vema Channel, at roughly $34.7 \mathrm{psu}$ and $0.5^{\circ} \mathrm{C}$ (Reid et al. 1977). The shape of the oxygen-salinity curve matches well a curve presented by Wüst (1935) for oxygen versus salinity on the bottom for a series of stations from the Argentine Basin to the Brazil Basin. Going north along the bottom is similar to going up the water column because water is sufficiently dense in the channel for both paths to profile a broad range of densities ${ }^{1}$ (and therefore broad enough to sample different water masses).

Geostrophic transport calculations using the $2^{\circ} \mathrm{C}$ isotherm as the zero velocity reference level imply a transport of $3.9 \times 10^{6} \mathrm{~m}^{3} \mathrm{~s}^{-1}$ through the Vema Channel below $2^{\circ} \mathrm{C}$ (all stations between 53 and 46, Fig. 3 ). This reference level choice is essentially the same as that of Hogg et al. (1982), who obtained $4.1 \times 10^{6}$ $\mathrm{m}^{3} \mathrm{~s}^{-1}$, and the result is the same within a reasonable error. The minimum temperature on the Vema Channel section $\left(-0.175^{\circ} \mathrm{C}\right)$ is slightly warmer than Hogg et al.'s $(1982)$ value $\left(-0.185^{\circ} \mathrm{C}\right)$, but the average temperature below $0^{\circ} \mathrm{C}$ is cooler: $-0.12^{\circ} \mathrm{C}$ versus $-0.09^{\circ} \mathrm{C}$. To the north of the section, the $0^{\circ} \mathrm{C}$ isotherm is confined entirely to the Brazil Basin, so equating inflow below $0^{\circ} \mathrm{C}$ to outflow across the $0^{\circ} \mathrm{C}$ isotherm allows a steady-state advective heat budget to be made for this layer in the basin. The net advective heat transport into the layer below $0^{\circ} \mathrm{C}$ is $-1.02 \times 10^{12} \mathrm{~W}(-240$ $\times 10^{9} \mathrm{cal} \mathrm{s}^{-1}$ ), a value $30 \%$ larger in magnitude than the Hogg et al. (1982) value of $-184 \times 10^{9} \mathrm{cal} \mathrm{s}^{-1}$. This, too, is thought to be the same result within plausible error. In a steady state, this cooling is balanced by a downward diffusion of heat.

These calculations suggest that the heat flux through the Vema Channel has not changed significantly over a ten-year period. Another measure of the apparent steadiness of the bottom water circulation pattern is the near equality of modern bottom potential temperatures with those measured during the I.G.Y. period and by the Meteor expedition in 1927. A comparison

\footnotetext{
${ }^{1}$ Wüst ( 1935) mistakenly attributed the oxygen minimum to aging along the bottom water path and to oxygen consumption on the rise, while correctly recognizing the need for subsequent mixing with overlying high oxygen North Atlantic Deep Water to raise values in the bottom water of the Brazil Basin.
} 

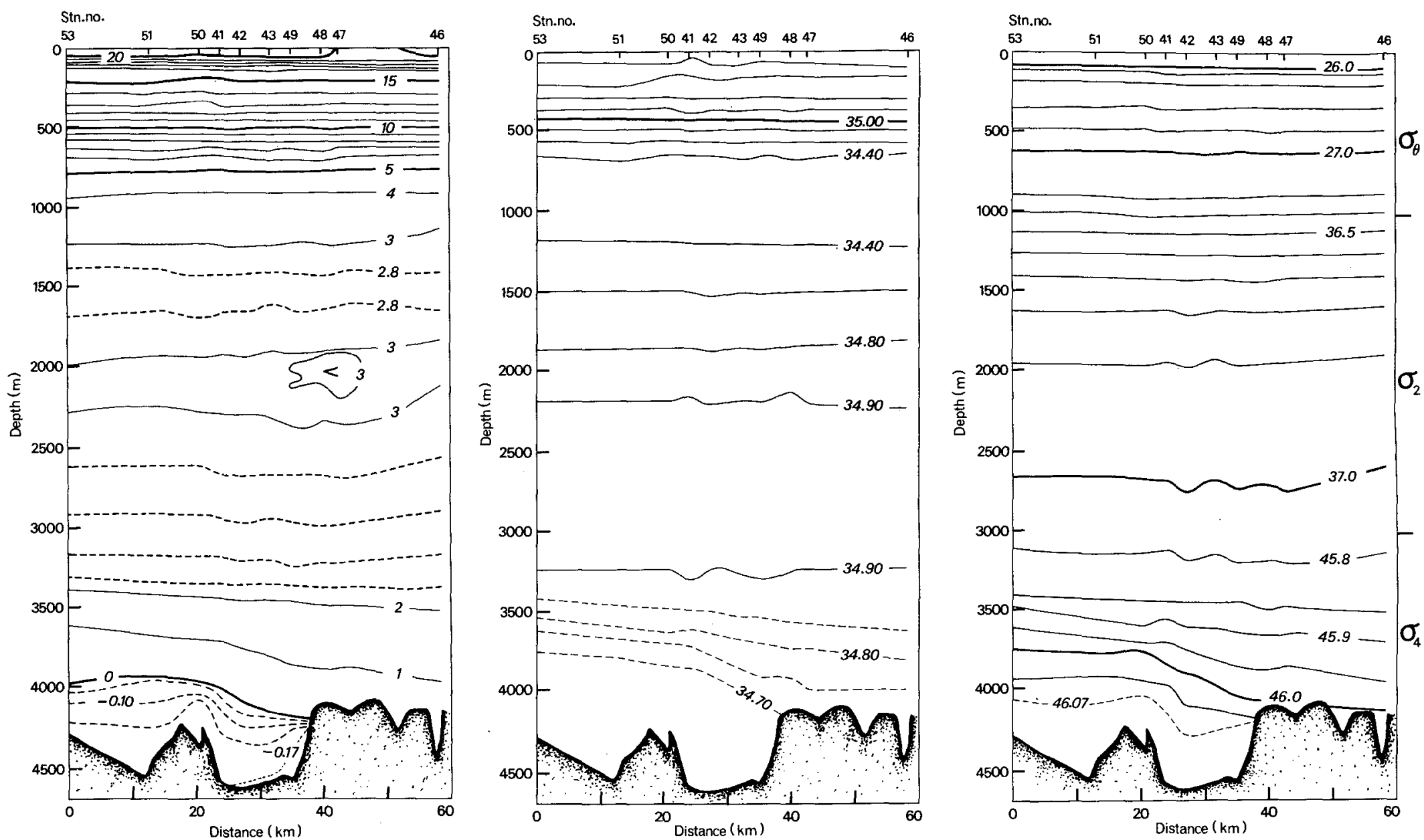

FIG. 4. (a) Profile of potential temperature $\left({ }^{\circ} \mathrm{C}\right.$ ) across the Vema Channel. Vertical distortion is $25: 1$. See Fig. 3 for station positions. (b) Profile of salinity (psu) across the Vema Channel. (c) Profile of potential density anomaly ( $\mathrm{kg} \mathrm{m}^{-3}$, see Fig. 2e) across the Vema Channel. 

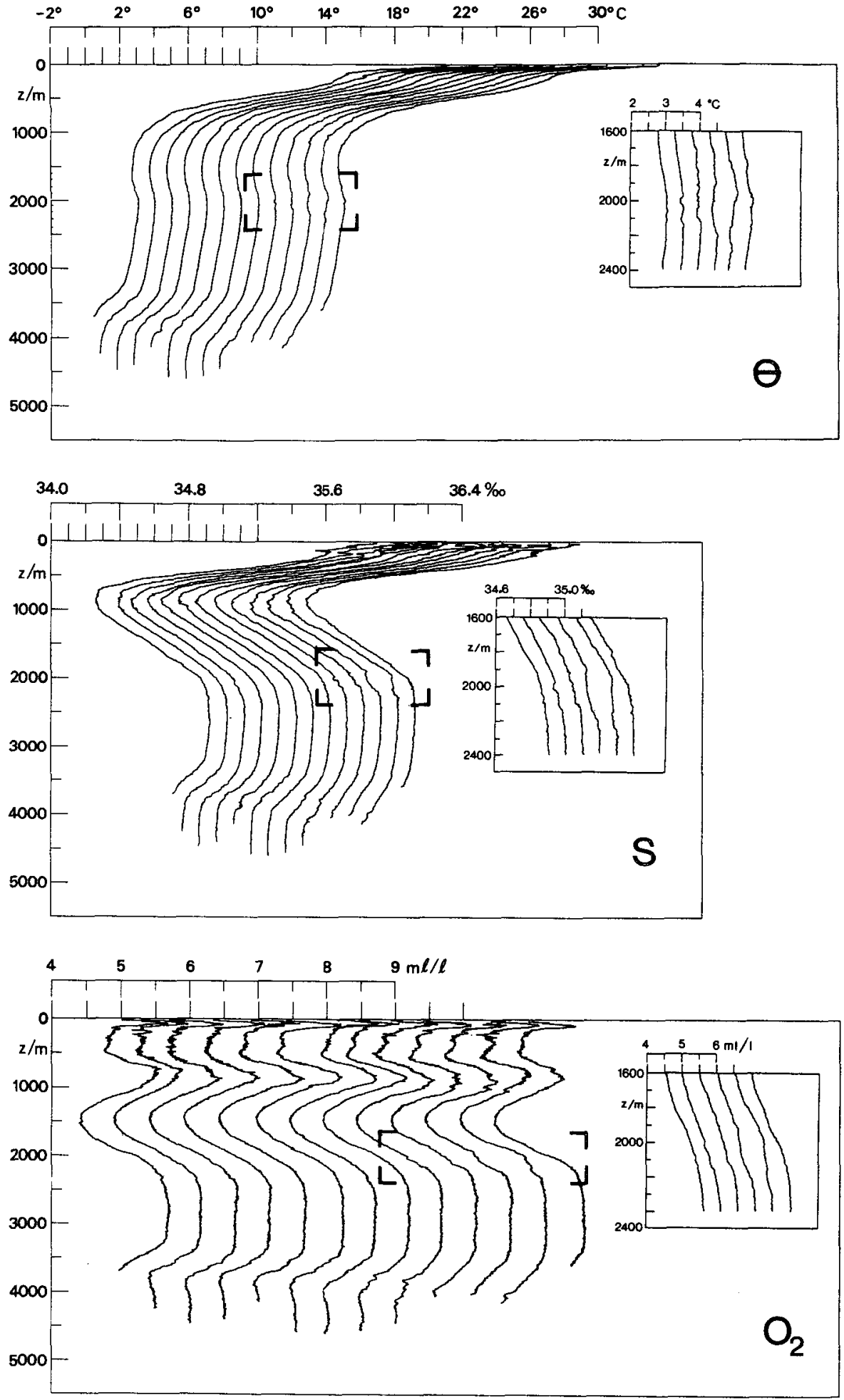

FiG. 5. Plots of potential temperature (upper), salinity (middle), and dissolved-oxygen concentration (lower) for Vema Channel stations $35,53,52,51,50,41,42,43,49,48,47,46,44$ from left to right. Each station is offset to show the horizontal distribution of small vertical-scale structure. The inset is a blowup of a lateral intrusion of Circumpolar Deep Water with cool, fresh, low oxygen characteristics. 

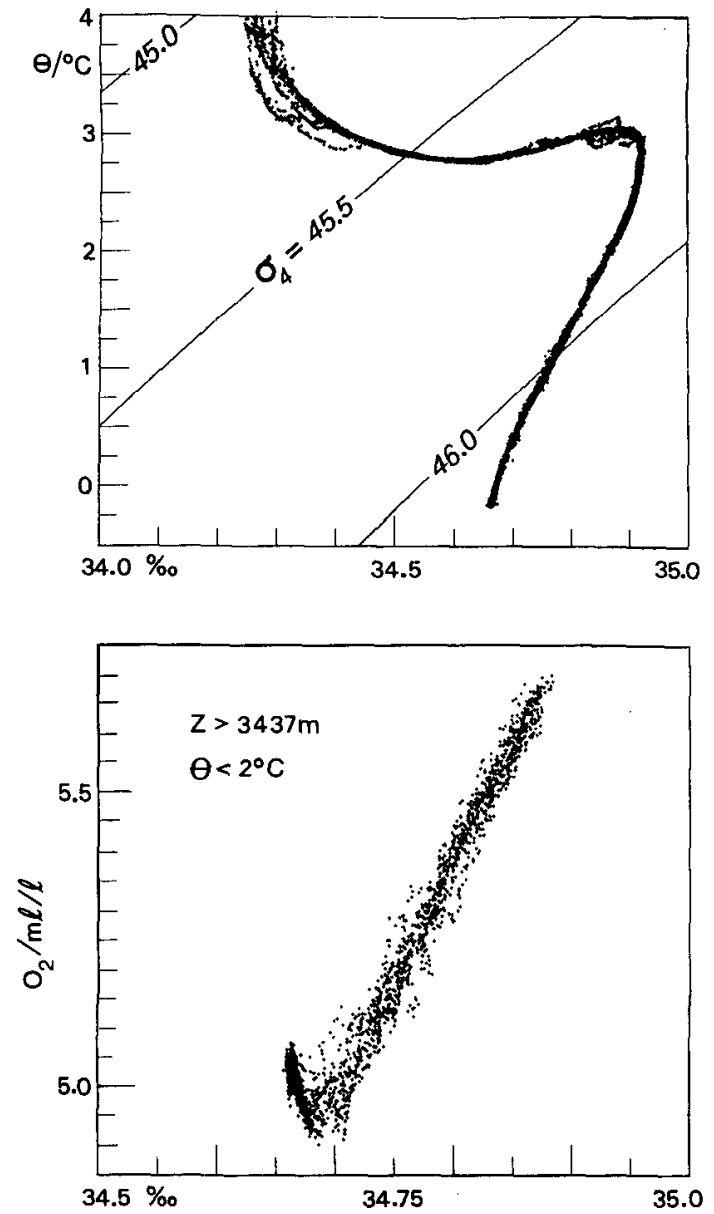

FIG. 6. Potential temperature-salinity (upper) and oxygen-salinity (lower) relation for stations in the Vema Channel (see caption to Fig. 5).

of four pairs of nearby Meteor, Crawford (I.G.Y.), and Melville (SAVE) stations on the Pernambuco Abyssal Plain showed a mean warming of $0.005^{\circ} \mathrm{C}$ $\left( \pm 0.005^{\circ} \mathrm{C}\right) / 10 \mathrm{yr}$. The change is not significant in view of the errors due to sampling a region with relatively strong horizontal and vertical temperature gradients.

Similar flux calculations were not made for the two warmer layers defined by Hogg et al. (1982): the additional flow above the plateau to the west of the Vema Channel and in the Hunter Channel would have to be added, probably doubling the input to these layers. This would tend to increase the resulting vertical mixing coefficients. On the other hand, the unknown loss of mass in these layers through the Romanche Fracture Zone and Chain Fracture Zone would have to be subtracted to calculate the net effect.

\section{d. The Hunter Channel}

The section across the Hunter Channel shows sloping isopycnals consistent with the northward flow of bot- tom water below about $3500 \mathrm{~m}$ depth (Fig. 7). The passage is roughly ten times broader than the Vema Channel, but horizontal gradients are weaker, signaling a much weaker current. The coldest water observed on the section was $0.16^{\circ} \mathrm{C}$ at the bottom of station 91 on the eastern side of the Hunter Gap (Fig. 7, near 200$\mathrm{km}$ distance; Fig. 1). Thus, the flow through the Hunter Channel consists entirely of the upper, warmer, and lower oxygen part of bottom water of circumpolar origin. It falls within the density range of lower circumpolar water defined by Reid (1989) as $45.85-46.07$ $\mathrm{kg} \mathrm{m}^{-3}$. The geostrophically estimated transport below a reference level surface at $2^{\circ} \mathrm{C}$ is $0.7 \times 10^{6} \mathrm{~m}^{3} \mathrm{~s}^{-1}$ (Speer et al. 1992; stations 84-87-94-89, Fig. 7).

Interestingly, a similar pattern of isotherm (or isopycnal) slope reversal is observed in the Hunter Channel as in the Vema Channel, at temperatures lower than $0.5^{\circ} \mathrm{C}$ (Fig. 7). The coldest water is therefore found on the eastern side of the gap. However, the effect seems to be less strong as an actual separation of layers from the eastern wall is not evident. In other words, the "pinching" of isotherms near the eastern wall is weaker in the Hunter Channel than in the Vema Channel.

Geostrophic velocity calculations suggest a bottom velocity of order $1 \mathrm{~cm} \mathrm{~s}^{-1}$ in the gap. Such a speed implies a vorticity scale only about $1 \%$ of the Coriolis parameter $f$, much less than the $10 \%$ or more possible with the higher velocity and greater confinement in the Vema Channel. It therefore seems unlikely that nonlinear dynamics controls the flow, but the question of whether or not frictional effects or hydraulic effects are crucial in the Hunter Channel cannot be addressed with the exploratory hydrographic measurements presented here. Hogg (1983) describes indications of hydraulic control involving up- and downstream potential energy changes, which require a number of hydrographic cross sections to be occupied along the path of the current. Moreover, quantitative estimates of stress are required, both near the bottom and in the level of strong shear above the bottom. Johnson and Sanford (1992) made such measurements in the Faroe Bank Channel and they emphasize the control exercised by the frictional, secondary flow over the cross-stream structure of isotherms.

The topography of the Hunter Channel region is complex. The main path taken by bottom water is through the northern extension of the Hunter Gap. A deeper valley just west of the gap is not continuous to the south into the Argentine Basin, and a station placed in it (station 94) showed a bottom temperature of $0.216^{\circ} \mathrm{C}$, more than $0.05^{\circ} \mathrm{C}$ warmer than in the gap itself. The water in the Hunter Fracture Zone (station 83 ) is warmer still, and in situ temperature shows a minimum above bottom, indicating a cul-de-sac. Downstream of the Hunter Gap a path for the coldest water can be sketched, based on recent measurements along $25^{\circ} \mathrm{W}$ (SAVE leg 5, HYDROS leg 3), other sta- 

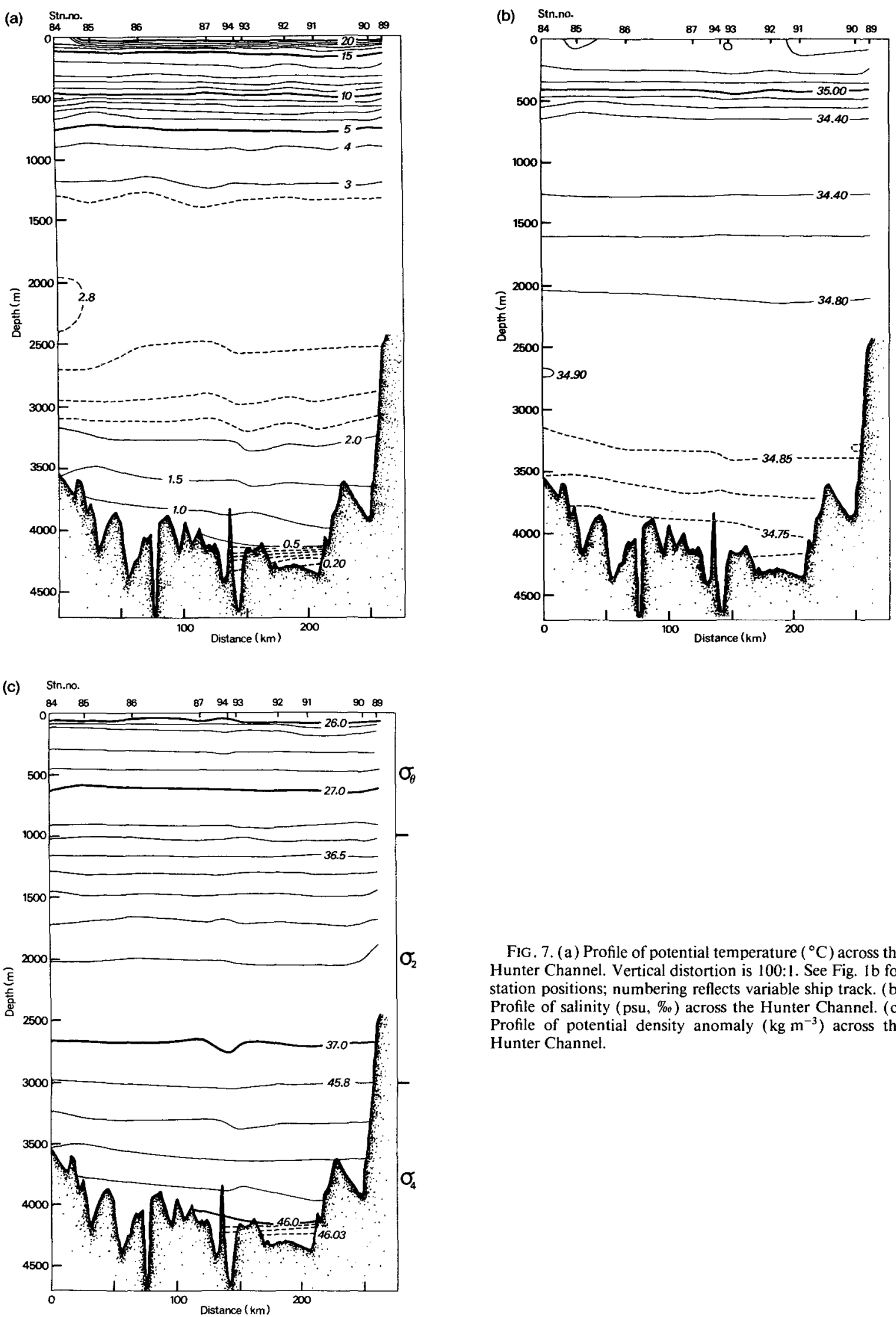

FIG. 7. (a) Profile of potential temperature $\left({ }^{\circ} \mathrm{C}\right)$ across the Hunter Channel. Vertical distortion is 100:1. See Fig. Ib for station positions; numbering reflects variable ship track. (b) Profile of salinity (psu, \%o) across the Hunter Channel. (c) Profile of potential density anomaly $\left(\mathrm{kg} \mathrm{m}^{-3}\right)$ across the Hunter Channel. 
tions occupied during the Meteor Cruise 15, and bathymetry (Cherkis et al. 1989; Fig. 8).

The warmer water continues north as a western boundary current along the Rio Grande Ridge, as determined by a short section near $31^{\circ} \mathrm{S}$ (Fig. 9). The geostrophic volume transport of this current below $2.4^{\circ} \mathrm{C}$ is $0.5 \times 10^{6} \mathrm{~m}^{3} \mathrm{~s}^{-1}$, somewhat less than that coming through the section to the south. It is natural to wonder if this flow continues all the way around the ridge and back south to the east of the Vema Channel. Another short section on the northern flank of the ridge shows that this is not the case (Fig. 9). The current diminishes to zero transport at the northern end of the ridge.

Reid et al. (1977) mapped the geostrophic flow at $4000 \mathrm{~m}$ relative to $3500 \mathrm{~m}$ (which is roughly the depth of the $2^{\circ} \mathrm{C}$ surface) for this region, showing interior flow directed to the northwest. At this level the only opening for a southern mass source is the Hunter Channel. Apparently the flow through the Hunter Channel eventually enters the main part of the Brazil Basin as a broader interior flow to the east of the Rio Grande Ridge. To reconcile the western boundary current at the Rio Grande Ridge with the interior flow mapped by Reid et al. (1977) and that demanded by the Stommel and Arons (1960) model, the vertical velocity should decrease upwards, compressing the water column and forcing northward flow. The interior flow is (in any case) fed by the western boundary current. Unfortunately, the lack of a reliable figure for the vertical velocity near $2^{\circ} \mathrm{C}$ makes it difficult to judge the relevance of this explanation. Calculations presented in the next section illustrate the strong upwelling across the dense isopycnals of the Vema Channel outflow in the Brazil Basin between the Rio Grande Rise, $24^{\circ} \mathrm{S}$, and $11^{\circ} \mathrm{S}$. At lower, intermediate densities typical of the Hunter Channel flow, the net mass convergence is less well determined.

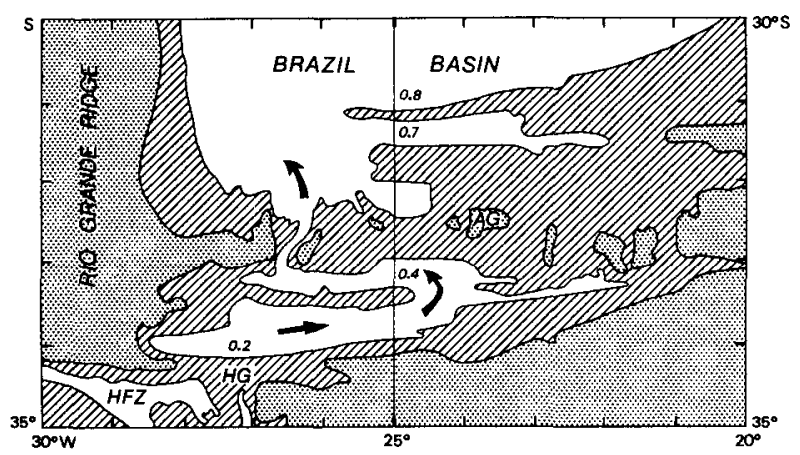

FIG. 8. Detailed bathymetry of Hunter Channel region according to Cherkis et al. (1989), including Hunter Fracture Zone (HFZ), Hunter Gap (HG), and Atlantis Gap (AG). Selected bottom potential temperature measurements $\left({ }^{\circ} \mathrm{C}\right)$ from Meteor 15 and HYDROS 5 are displayed (numbers). Areas shallower than $4400 \mathrm{~m}$ to $4000 \mathrm{~m}$ are striped, less than $4000 \mathrm{~m}$ stippled. Arrows show likely path of coldest water into the Brazil Basin.
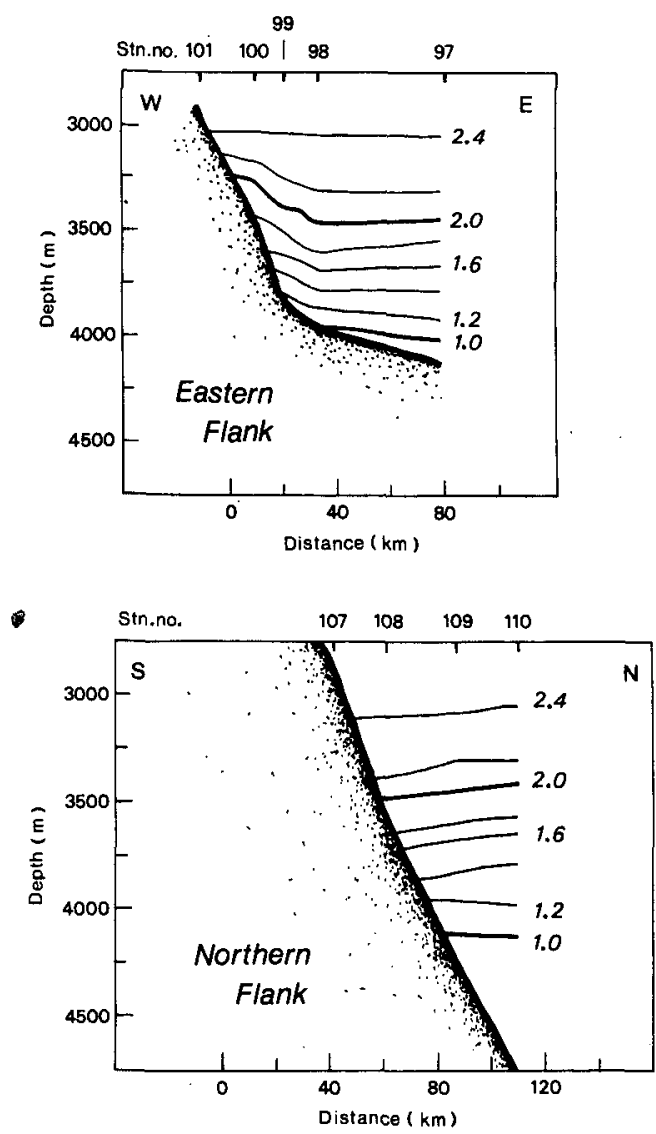

FIG . 9. Profiles of potential temperature $\left({ }^{\circ} \mathrm{C}\right)$ above the eastern flank (upper) and northern flank (lower) of the Rio Grande Ridge. See Fig. $1 \mathrm{~b}$ for station positions. A boundary current is evident above the eastern flank and absent to the north.

\section{Transport calculations}

A number of zero velocity reference surface choices were tried, all in the vicinity of $2^{\circ} \mathrm{C}$. This isotherm has been used traditionally, and calculations based on it are useful for comparison. In addition, Hogg et al.'s (1982) direct measurements of flow in the Vema Channel implied a level of no motion near this isotherm. A plot of potential temperature versus salinity on station 15 above the Lower Santos Plateau shows no special change in salinity at this temperature; however, oxygen does decrease markedly below it, signaling the transition between deep and bottom water (Fig. 10 ). In the end, a zero velocity surface on the isopycnal $45.85 \mathrm{~kg} \mathrm{~m}^{-3}$ was chosen to be applied throughout. This surface is quite close to $2^{\circ} \mathrm{C}$ at $30^{\circ} \mathrm{S}$, but nearer to $2.1^{\circ} \mathrm{C}$ at $24^{\circ} \mathrm{S}$ and $11^{\circ} \mathrm{S}$.

Net transport estimates with this reference level choice are compared with others in Table 1. Based on the standard deviation of transport for each station pair, and modest reference level changes, the expected errors together with section net transports are $6.7( \pm 0.4)$ $\times 10^{6} \mathrm{~m}^{3} \mathrm{~s}^{-1}$ at $30^{\circ} \mathrm{S}, 5.0( \pm 1.1) \times 10^{6} \mathrm{~m}^{3} \mathrm{~s}^{-1}$ at $24^{\circ} \mathrm{S}$, 

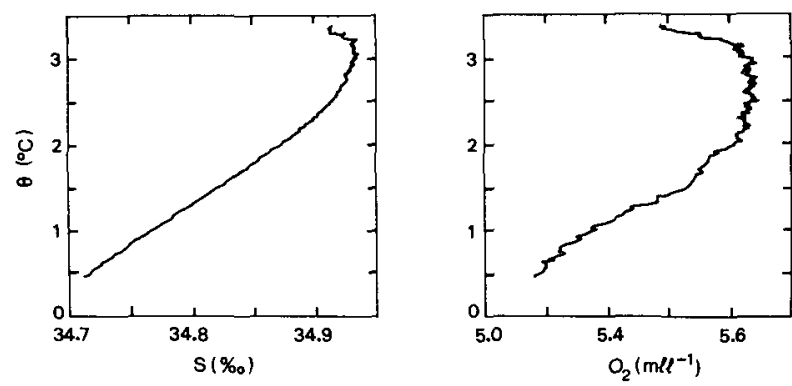

FIG. 10. Potential temperature-salinity and potential temperatureoxygen diagram for Meteor 15 station 15 above the lower Santos Plateau, centered on $2^{\circ} \mathrm{C}$.

and $3.0( \pm 1.4) \times 10^{6} \mathrm{~m}^{3} \mathrm{~s}^{-1}$ at $11^{\circ} \mathrm{S}$ (Table 1$)$. McCartney and Curry (1993) used $1.9^{\circ} \mathrm{C}$ as a reference surface with somewhat higher results at $24^{\circ} \mathrm{S}$ and $11^{\circ} \mathrm{S}$. Our result using $1.9^{\circ} \mathrm{C}$ at $11^{\circ} \mathrm{S}$ is $4.5 \times 10^{6} \mathrm{~m}^{3} \mathrm{~s}^{-1}$. Clearly the $11^{\circ} \mathrm{S}$ result is less reliable because of its greater sensitivity to reference level, station spacing, and bottom triangle calculation choices.

With a section across the Santos Plateau and Vema Channel (but not the Hunter Channel), Zemba (1991) calculated a bottom water transport of $4.3 \times 10^{6} \mathrm{~m}^{3} \mathrm{~s}^{-1}$ using the same isopycnal reference surface as ours. Essentially all $\left(4.1 \times 10^{6} \mathrm{~m}^{3} \mathrm{~s}^{-1}\right)$ of this was in the Vema Channel, implying a net cancellation across the Santos Plateau. The reason for the discrepancy is not clear, but may be due to a factor of two lower resolution.

The transport of bottom water across the rise has been broken down into density classes separated by $0.02 \mathrm{~kg} \mathrm{~m}^{-3}$, an interval small enough to resolve the different water mass structure and large enough to include a reasonable portion of the flow. The transport is further divided into results for the Vema Channel, the Hunter Channel, and the full section (Fig. 11). In these density coordinates, the Hunter and Vema Channel have comparable contributions. The distinguishing feature of the Vema Channel transport is the relatively large amount $\left(2.5 \times 10^{6} \mathrm{~m}^{3} \mathrm{~s}^{-1}\right)$ of Weddell Sea Deep Water denser than $46.05 \mathrm{~kg} \mathrm{~m}^{-3}$ flowing north. This water is the single most important source in density coordinates (or temperature-salinity classes). Changing the reference level between 45.80 and $45.90 \mathrm{~kg} \mathrm{~m}^{-3}$ does not change much the relative contribution of each class, though the absolute amount

TABLE 1. Bottom water transport $\left(10^{6} \mathrm{~m}^{3} \mathrm{~s}^{-1}\right)$ in the western South Atlantic. Error estimates are included in parentheses.

\begin{tabular}{lcccl}
\hline \hline & $30-32^{\circ} \mathrm{S}$ & $24^{\circ} \mathrm{S}$ & $19^{\circ} \mathrm{S}$ & $11^{\circ} \mathrm{S}$ \\
\hline This study & $6.7(0.4)$ & $5.0(1.1)$ & $4.5(0.8)$ & $3.0(1.4)$ \\
McCartney and & & 6.7 & & \\
$\quad$ Curry (1993) & - & 6.4 & $4.4^{+}$ & $2.5^{*}$ \\
Wright (1970) & 5 & 6.4 & \\
\hline
\end{tabular}

* Average of $8^{\circ} \mathrm{S}$ and $16^{\circ} \mathrm{S} .{ }^{+}$Average of $16^{\circ} \mathrm{S}$ and $24^{\circ} \mathrm{S}$.

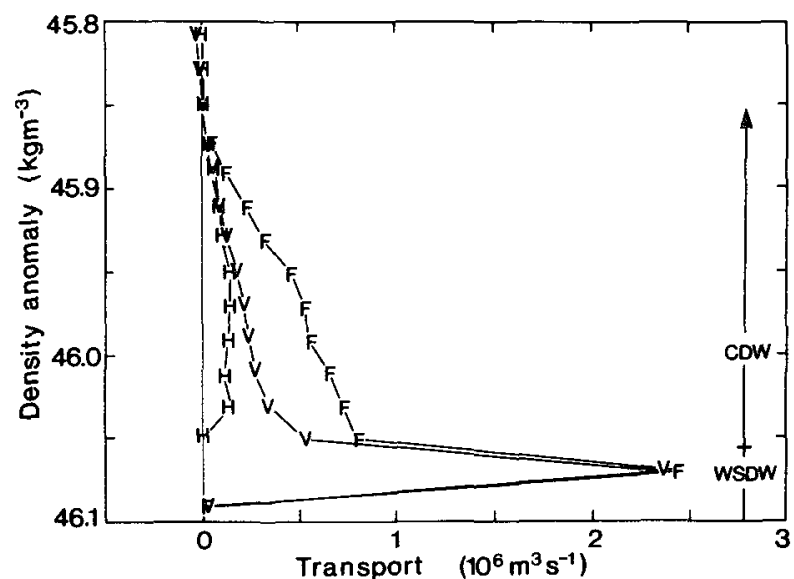

FiG. 11. Geostrophic transport $\left(10^{6} \mathrm{~m}^{3} \mathrm{~s}^{-1}\right)$ of bottom water in density classes $\left(\mathrm{kg} \mathrm{m}^{-3}\right.$, potential density anomaly referenced to 4000 $\mathrm{db}$, EOS 80). Results for Hunter Channel (H), Vema Channel (V), and full section (F) are displayed; Circumpolar Deep Water (CDW) and Weddell Sea Deep Water (WSDW) ranges are indicated to the right.

changes. The full section result includes flow above the lower Santos Plateau, and it is these warmer classes above $46.05 \mathrm{~kg} \mathrm{~m}^{-3}$ that experience strong modification of properties across the rise; the densest class remains the same for some distance into the Brazil Basin (Hogg et al. 1982; Reid 1989; Mantyla and Reid 1983), until cross-isopycnal entrainment begins to dilute it.

The downstream evolution of transport in density classes has been calculated using Oceanus (Cruise 133) data at $24^{\circ} \mathrm{S}$ and $11^{\circ} \mathrm{S}$. Along with the vertical distribution by density class, the horizontal structure of the flow is illustrated by plotting the total transport below the reference level cumulatively along the sections (Fig. 12). The large transport in the densest nonempty class at $30^{\circ} \mathrm{S}$ diminishes from $30^{\circ} \mathrm{S}$ to $24^{\circ} \mathrm{S}$, and essentially vanishes at $11^{\circ} \mathrm{S}$, by which point mixing has eliminated water in this class. The implied cross-isopycnal transport due to this convergence increases as density decreases at first, decreases slightly, and finally increases up to the reference level. It is the rather weak transport at lower densities through the $24^{\circ} \mathrm{S}$ and especially the $11^{\circ} \mathrm{S}$ section that forces a general increase in upwelling across isopycnals. At $11^{\circ} \mathrm{S}$ all the transport is concentrated in only two classes creating a sink at $46.03 \mathrm{~kg} \mathrm{~m}^{-3}$ and thereby reducing the cross-isopycnal component at this density. These general trends hold up under modest reference level changes, with the most sensitive dependence being on the $11^{\circ} \mathrm{S}$ results.

The horizontal structure shows transport growing rapidly with the main northward flow, reversing in a southward circulation, and then building up again to a lesser degree from west to east across the basin (Fig. 12). This structure is displayed geographically in Fig. 13, together with round-number transports. Transport values at the equatorial exits are based on estimates by 
VERTICAL
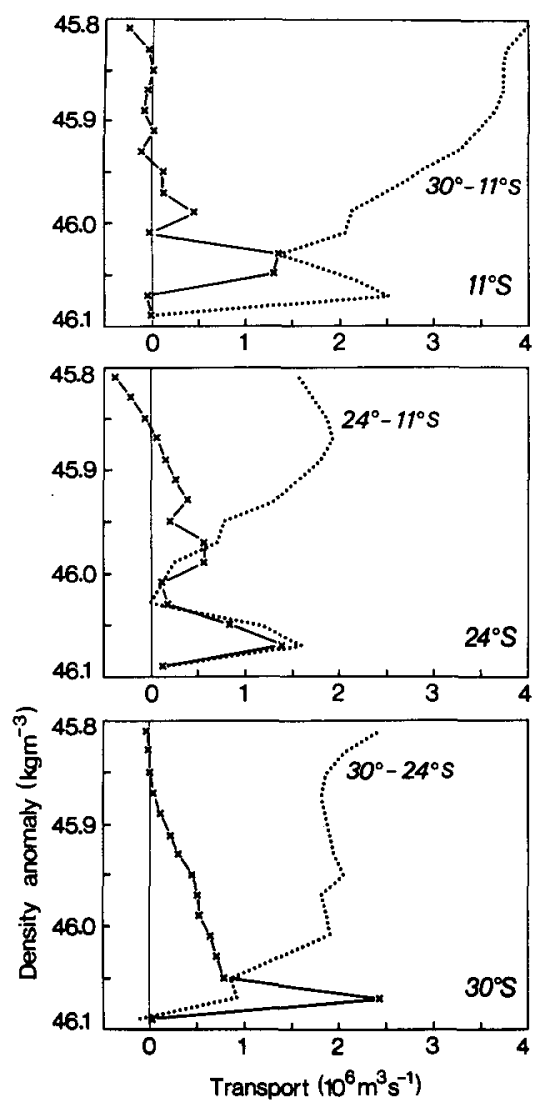

HORIZONTAL
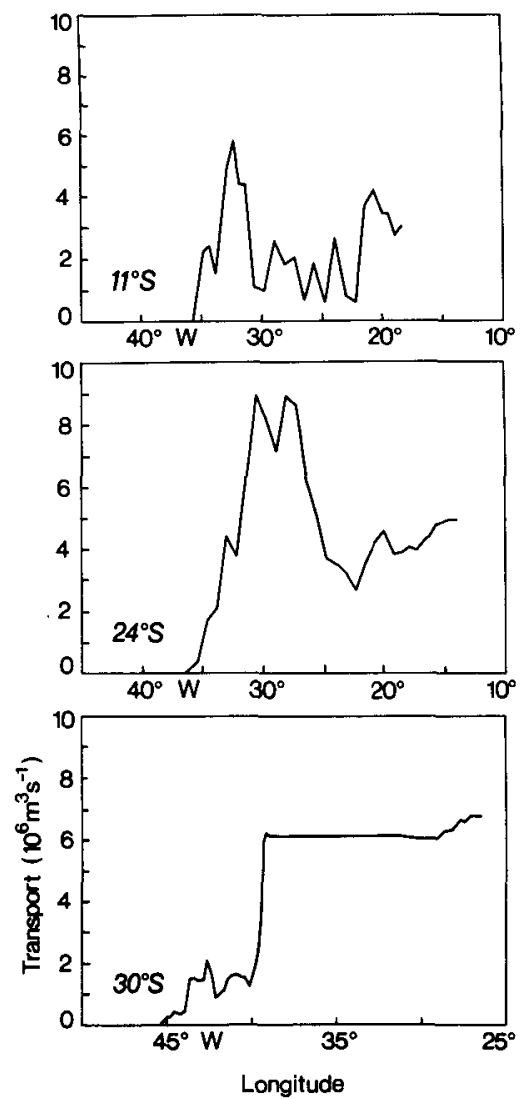

FIG. 12. Geostrophic bottom water transport $\left(10^{6} \mathrm{~m}^{3} \mathrm{~s}^{-1}\right)$ for Meteor 15 nominally at $30^{\circ} \mathrm{S}$, and Oceanus 133 at $24^{\circ} \mathrm{S}$ and $11^{\circ} \mathrm{S}$. Crosses mark transport calculated in density classes as in Fig. 11, dots mark area-integrated cross-isopycnal upwelling between sections, calculated as the transport difference integrated from the maximum density to lower densities. On the right the vertically integrated bottom water transport is summed cumulatively from west to east and displayed as a function of longitude.

McCartney and Curry (1993) and Warren and Speer (1991). Results at $19^{\circ} \mathrm{S}$ are similar to $24^{\circ} \mathrm{S}$ and are not displayed. According to these calculations, horizontal recirculation is a basic part of the flow and is of strength similar to the net northward throughflow.

\section{Discussion}

If an upwelling of $4 \times 10^{6} \mathrm{~m}^{3} \mathrm{~s}^{-1}$ between $30^{\circ} \mathrm{S}$ and $11^{\circ} \mathrm{S}$ is spread out uniformly over the area of the 45.85 $\mathrm{kg} \mathrm{m}^{-3}$ isopycnal, about $5 \times 10^{12} \mathrm{~m}^{2}$, the cross-isopycnal speed is $8 \times 10^{-5} \mathrm{~cm} \mathrm{~s}^{-1}$. This value is very high, more than twice that estimated for the Angola Basin at $4000 \mathrm{~m}$ depth $\left(3.1 \times 10^{-5} \mathrm{~cm} \mathrm{~s}^{-1}\right.$, Warren and Speer 1991). If the net northward transport of bottom water at $11^{\circ} \mathrm{S}$ is really closer to the upper end of estimates (Table 1), or about $5 \times 10^{6} \mathrm{~m}^{3} \mathrm{~s}^{-1}$, then the average upwelling is half as large, $4 \times 10^{-5} \mathrm{~cm} \mathrm{~s}^{-1}$. This still seems high. However, the upwelling has to be high somewhere downstream of the Rio Grande
Rise, since spreading out the $7 \times 10^{6} \mathrm{~m}^{3} \mathrm{~s}^{-1}$ inflow over the area of all basins fed by this source (say 30 $\times 10^{12} \mathrm{~m}^{2}$ at $4000 \mathrm{~m}$ ) requires an average vertical velocity of about $2 \times 10^{-5} \mathrm{~cm} \mathrm{~s}^{-1}$.

At $11^{\circ} \mathrm{S}$ and $24^{\circ} \mathrm{S}$ the net northward transport throughout the intermediate density range 45.90-46.01 $\mathrm{kg} \mathrm{m}^{-3}$ is relatively weak, even canceling altogether at certain densities (Fig. 12). This can be due to weak northward flow, or stronger flow with both north and south components. By looking at results for individual station pairs in this density range we can see that the latter is true and that the horizontal structure is simple, with northward flow in the west and southward flow in the middle of the basin. Reid's (1989) maps of properties on the $45.97 \mathrm{~kg} \mathrm{~m}^{-3}$ isopycnal are supportive, showing extrema of northerly origins located in the middle of the basin, and opposite characteristics along the western boundary.

On the other hand, these same features of the property distributions are attributed by Reid (1989) to ver- 


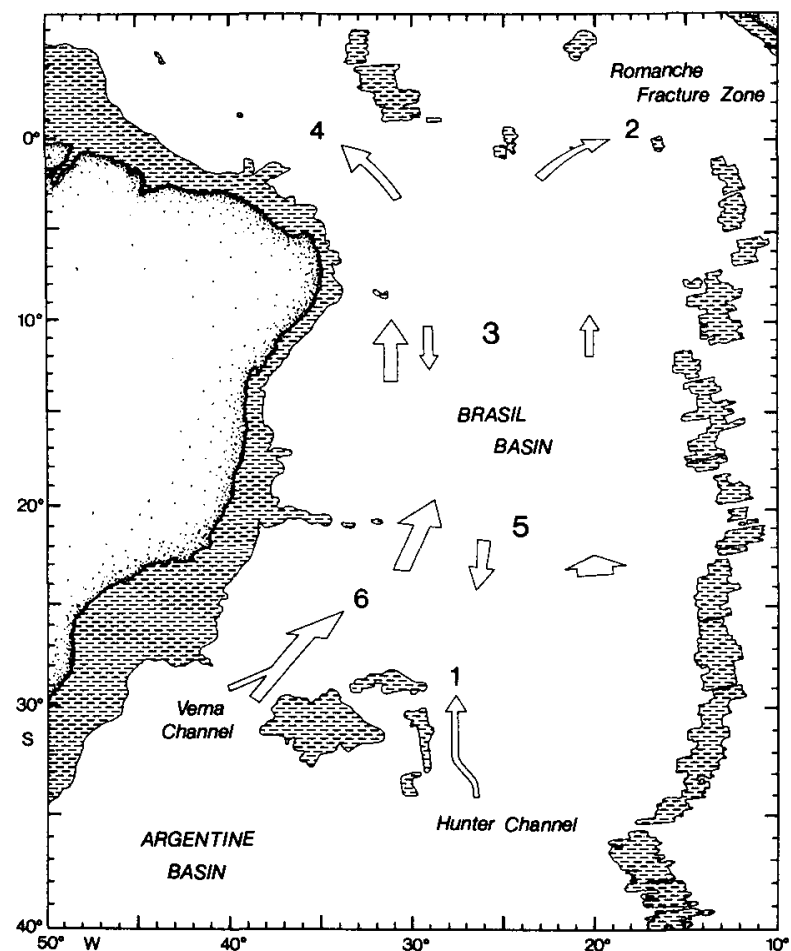

FIG. 13. Schematic of bottom water flow in the Brazil Basin. Areas shallower than $3000 \mathrm{~m}$ stippled. Round-number net transports are shown, based on geostrophic flow calculations (see Fig. 12), and estimates of losses at the equator ( see text).

tical mixing in a uniform northward flow. The different flows are due to a different reference level choice. The $45.85 \mathrm{~kg} \mathrm{~m}^{-3}$ isopycnal used here as the reference level for geostrophic calculations lies at a depth between 3400 and $3600 \mathrm{~m}$. Reid's (1989) flow at $3500 \mathrm{dbar}$, however, is not zero, but northward in the interior (and southward next to the western boundary). This is apparently due to the northward bottom velocity added to calculations of geostrophic flow at $11^{\circ} \mathrm{S}, 16^{\circ} \mathrm{S}$, and $24^{\circ} \mathrm{S}$. Such bottom flow was needed to correct the initial calculation, which used a reference level at the bottom, and which otherwise would produce southward flowing bottom water. Instead of bringing the flow to zero near $3500 \mathrm{~m}$, the added bottom velocities are strong enough to impose northward flow in the interior throughout the deep water.

Reid's ( 1989) study was broader in scope, and constraints in other layers and even other regions may have helped to fix the bottom reference level velocities. Despite their differences, both studies show a general northward flow of bottom water, concentrated in the west. The differences, however, should be important to quantitative estimates of mixing: in one the flow is everywhere northward and vertical mixing is very strong, in the other a recirculation to the south exists and mixing is less strong at intermediate densities.

Dynamics may help to support a case for southward flow. The Stommel and Arons (1960) model requires southward flow in a Southern Hemisphere basin, but this model presumes that the bottom is flat and that the vertical velocity increases with height above the bottom (vortex stretching). Geostrophic contours in the Brazil Basin are modified by bottom topography (Fig. 14), and by the shape of whichever surface is presumed to be the upper boundary of bottom water. Isopycnals near $45.85 \mathrm{~kg} \mathrm{~m}^{-3}$, for instance, descend by roughly $200 \mathrm{~m}$ from south to north in midbasin. Upwelling on warped geostrophic contours should tend to generate southward as well as northward motion because water supplied to the interior from the western boundary current follows geostrophic contours. If the effects are strong enough to close the contours, then strong interior gyres may be spun up. The inferred anticyclonic circulation in the interior is at least consistent with a strong modification of flow by the geostrophic contours, and provides a basis for quantitative investigations.

Bottom water transport across the Rio Grande Rise is about $40 \%$ Weddell Sea Deep Water and 60\% lower Circumpolar Deep Water. The bottom water of the Brazil Basin and basins to the north is often described as consisting entirely of lower Circumpolar Deep Water. However, the transport calculation in density classes avoids ambiguous layer definitions and implies that nearly half of this "circumpolar" water in the Brazil Basin is formed there by the vertical mixing of Weddell Sea Deep Water with true circumpolar water. This suggests a more passive role for the circumpolar water mass, with motion largely driven by denser water below it. Above the Lower Santos Plateau and in the Hunter

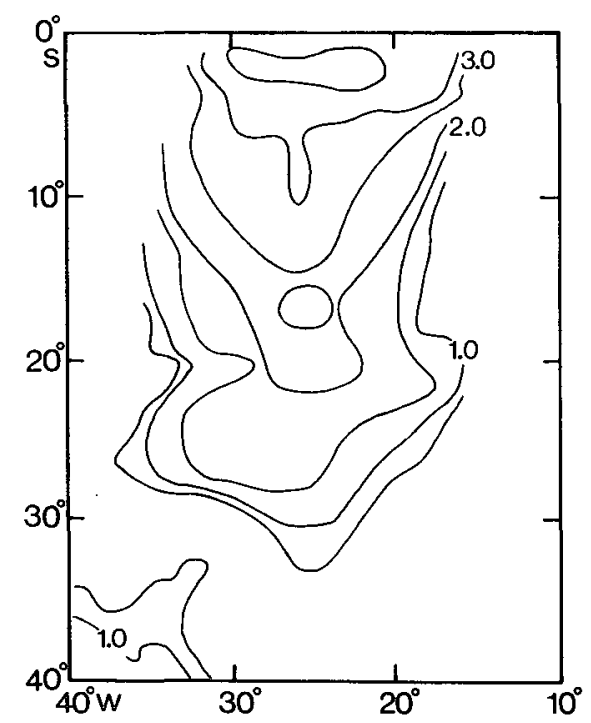

Fig. 14. Plot of geostrophic contours in the Brazil Basin ln $(\mathrm{H} /$ $f$ ), where $H$ is the distance between $4000 \mathrm{~m}$ and the bottom, and $f$ is the Coriolis parameter ( $a$ constant offset of -20.7 has been added for labeling convenience). 
Channel, though, all the transport is in the circumpolar range, showing that the upwelling across the top of bottom water to the north of the Rio Grande Rise is not adequately supplied by the Weddell Sea Deep Water mass alone. The mixing and entrainment that occurs along the equatorial passages and within basins farther north forces, at these densities, an additional northward transport into the Brazil Basin.

The new elements of bottom water flow across the Rio Grande Rise identified above the Santos Plateau and in the Hunter Channel are smaller than that through the Vema Channel. They nevertheless have a significant role in the mass balance of Antarctic Bottom Water and in the dynamics of its circulation. Both of these circulation elements are western boundary currents and add support to simple large-scale dynamics, which requires such currents to feed interior flow; not finding a current at a western boundary would have been more difficult to rationalize.

Acknowledgments. This work was jointly funded by the Deutsche Forschungsgemeinschaft (Si 111/38-1) and Bundesministerium für Forschung und Technologie (03F0050D), in grants to G. Siedler, whose support is appreciated. Many valuable computations were made by $M$. Vanicek, and the help of K. Schultz-Tokos with the data calibration was crucial. Careful reading by a reviewer is appreciated. The spirit of cooperation within the Deep Basin Experiment group has been an asset. Current support for K.S. comes from the CNRS. The SAVE and HYDROS data were generously provided by W. Smethie, M. McCartney, and L. Talley.

\section{REFERENCES}

Cherkis, N. Z., H. S. Fleming, and J. M. Brozena, 1989: Bathymetry of the South Atlantic Ocean, $3^{\circ} \mathrm{S}-40^{\circ} \mathrm{S}$. Geol. Soc. Amer. Map and Chart Series-MCH 069.

Fuglister, F. C., 1960: Atlantic Ocean Atlas of Temperature and Salinity Profiles and Data from the International Geophysical Year of 1957-1958. Woods Hole Oceanographic Institution, $209 \mathrm{pp}$.

Hogg, N. G., 1983: Hydraulic control and flow separation in a multilayered fluid with applications to the Vema Channel. $J$. Phys. Oceanogr., 13, 695-708.
- , P. Biscaye, W. Gardner, and W. J. Schmitz, Jr., 1982: On the transport and modification of Antarctic Bottom Water in the Vema Channel. J. Mar. Res., 40(Suppl.), 231-263.

Johnson, D. A., S. E. McDowell, L. G. Sullivan, and P. E. Biscaye, 1976: Abyssal hydrography, nephelometry, currents, and benthic boundary layer structure in the Vema Channel. J. Geophys. Res., 81, 5771-5786.

Johnson, G. C., and T. B. Sanford, 1992: Secondary circulation in the Faroe Bank Channel outflow. J. Phys. Oceanogr., 22, 927933.

McCartney, M. S., and R. C. Curry, 1993: Transequatorial flow of Antarctic Bottom Water in the Western Atlantic Ocean: Abyssal geostrophy at the equator. $J$. Phys. Oceanogr., 23, 1264-1276.

Mantyla, A. W., and J. L. Reid, 1983: Abyssal characteristics of the World Ocean waters. Deep-Sea Res., 30, 805-833.

Reid, J.L., 1989: On the total geostrophic circulation of the South Atlantic Ocean: Flow patterns, tracers, and transports. Progress in Oceanography, Vol. 23, Pergamon, 149-244.

- W. D. Nowlin, Jr., and W. C. Patzert, 1977: On the characteristics and circulation of the southwestern Atlantic Ocean. $J$. Phys. Oceanogr., 7, 62-91.

Siedler, G., and W. Zenk, 1992: WOCE Südatlantik 1991, reise nr. 15, Dez. 1990-März 1991. Meteor-Berichte, 92(1), 126 pp.

Speer, K. G., W. Zenk, G. Seidler, J. Pätzold, and C. Heidland, 1992: First resolution of flow through the Hunter Channel in the South Atlantic. Earth Planet. Sci. Lett., 113, 287-292.

Stommel, H., and A. Arons, 1960: On the abyssal circulation of the world ocean-1. Stationary planetary flow patterns on a sphere. Deep-Sea Res., 6, 140-154.

Warren, B. A., and K. G. Speer, 1991: Deep circulation in the eastern South Atlantic Ocean. Deep-Sea Res., 38(Suppl.), 281-322.

Wright, W. R., 1970: Northward transport of Antarctic Bottom Water in the western Atlantic Ocean. Deep-Sea Res., 17, 367-371.

Wüst, G., 1933: Das Bodenwasser und die Gliederung der Atlantischen Tiefsee. Wissenschaftliche Ergebnisse der Deutschen Atlantischen Expedition auf dem Vermessungs-und Forschungsschiff "Meteor" 1925-1927, Vol. 6(1), 1-107.

, 1935: Schichtung und Zirkulation des Atlantischen Ozeans. Die Stratosphare. Wissenschaftliche Ergebnisse der Deutschen Atlantischen Expedition auf dem Forschungsund Vermessungsschiff "Meteor" 1925-1927, Vol. 6(1), 180 pp. [The Stratosphere of the Atlantic Ocean, W. J. Emery, Ed., 1978, Amerind, 112 pp.]

1955: Stromgeschwindigkeiten im Tiefen- und Bodenwasser des Atlantischen Ozeans auf Grund Dynamischer Berechnungen der Meteor-Profile der Deutschen Atlantischen Expedition 192527. Deep-Sea Res., 3(Suppl.), 373-397.

Zemba, J. C., 1991: The structure and transport of the Brazil Current between $27^{\circ}$ and $36^{\circ} \mathrm{S}$. Ph.D. thesis, MIT-WHOI Joint Program in Oceanography, Woods Hole, MA., $160 \mathrm{pp}$.

Zenk, W., K. G. Speer, and N. Hogg, 1993: Batymetry at the Vema Sill. Deep-Sea Res., 40, 1925-1933. 